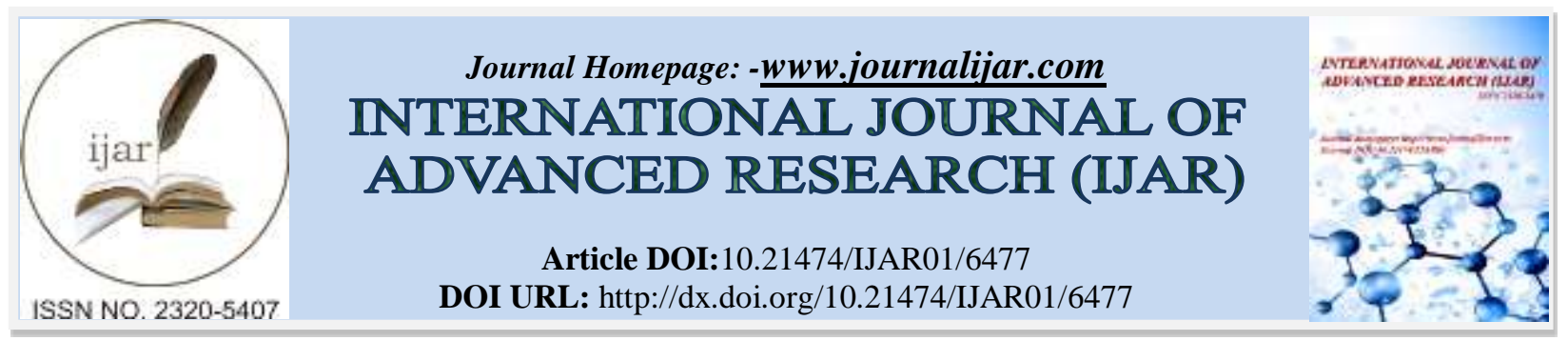

RESEARCH ARTICLE

\title{
A REPORT ON FRESH WATER BIVALVES AND THEIR SHELL STRUCTURE FROM LUCKNOW (U.P.) INDIA.
}

\author{
Sanjive Shukla ${ }^{1}$, Sanjay Shukla ${ }^{2}$, Richa Shukla ${ }^{3}$, Sandeep Shukla ${ }^{1}$, Jaya Sharma ${ }^{4}$ and U. D. Sharma ${ }^{5}$. \\ 1. Post-Graduate Department of Zoology, B.S.N.V. P.G. College, Lucknow (U.P.) India-226001 \\ 2. Department of Geology, B.S.N.V. P.G. College, Lucknow. \\ 3. Department of Zoology, N.K.V. P.G. College, Lucknow. \\ 4. Department of Zoology, Rajat Degree College, Lucknow. \\ 5. Retd. Professor, Department of Zoology, University of Lucknow, Lucknow.
}

\section{Manuscript Info}

Manuscript History

Received: 08 December 2017

Final Accepted: 10 January 2018

Published: February 2018

\section{Keywords:-}

Freshwater mussel, Lamellidens marginalis, Parreysia favidens, Pearl culture.

\section{Abstract}

Two fresh water bivalves viz. Lamellidens marginalis and Parreysia favidens were recorded from water reservoirs in and around Lucknow (U.P.) India. Shell microstructure of both the species indicates presence of periostracum, prismatic and nacreous layers. The shell of $P$. favidens appeared thicker, particularly the nacreous layer. Behaviour of both bivalve species as well as their prospective role in pearl culture industry has been discussed.

\section{Introduction:-}

Fresh water mussel belongs to order Unionida, Class-Bivalvia of Phylum-Mollusca, a second abundant group of animal kingdom. They are distributed in fresh water rivers, lakes, ponds, puddles etc. throughout the world particularly south and Central Asia (Abot, 1989).

Fresh water mussels are found buried in the bottom bed and feed on algae, planktons and bacteria. These bivalves are important constituents of fresh water food chain, performs water purification as well as serve good bioindicators of aquatic ecosystem (Crabarkiewicz and Davis, 2008; Pashupuleti and Subba Rao, 2015; Sultana et al., 2016 and Dhaneswari and Sanjeevi, 2016). Mussel tissues as well as shell accumulates most of the xenobiotics therefore are widely used in environmental monitoring (Dailians, 2010).

Freshwater mussels are widely used in pearl industry, button industry, medicines, as food etc. since long (Mishar, 2005; Safaktullah and Krishnamoorti, 2014; Dhaneswari and Sanjeevi, 2016). Freshwater pearl culture is an emerging enterprise across the Asia now days, which is directly linked with the type of shell and secretion of nacre (Mishra et al., 2009).

The shell structure and growth patterns have been studied in scattered manner on very few genera (Thomas, 1974; Ravindranath and Ravindranath, 1974; Begum et al., 1993; Begum et al., 2000; Goosling, 2003).

Considering above facts the present work has been taken to investigate Bionomics and shell structure of two fresh water mussels, L. marginalis and P. favidens from Lucknow (U.P.) India, which may have their potential role in fresh water pearl Industry as well as ecological and bio-indicator performance in environmental monitoring. 


\section{Material and Methods:-}

Fresh water bivalves, Lemellidens marginalis (Lamarck) and Parreysia favidens (Benson) were collected from river Gomti and other water reservoirs in and around Lucknow (U.P.) India with the help of local fisherman and brought to laboratory (N-26 $\left.{ }^{\circ} 49^{\prime}, 55^{\prime \prime}, \mathrm{E}-80^{\circ} 55^{\prime}, 58^{\prime \prime}\right)$ and maintained in $20 \mathrm{~L}$ glass aquaria containing 1 inch bed of clay in water having physico-chemical characteristics as Follows: $\mathrm{pH}=7.6 \pm 0.2$, Temp $=26 \pm 2^{\circ} \mathrm{C}, \mathrm{D} . \mathrm{O} .=7.0 \pm 0.1 \mathrm{mg} / 1$, Hardness $=298 \pm 2.5 \mathrm{mg} / \mathrm{l}$, Alkalinity $=65 \pm 405 \mathrm{mg} / \mathrm{l}$ (Verma et al., 2012)

Behavioural observations were carefully recorded and shell morphology was studied for identification (ZSI; Subba Rao, 1989). For microscopic structure of shell, shell valves were cleaned with water using nylon brush, cooked in canada balsum and cooled for 2-3 times. Hardened shells were cut transversely on cutting machine. Cut pieces were grinded polished and stained with Alizarin Red-S stain for Calcite/ aragonite crystals before grinding. Section were fixed and mounted on glass slides as per method of Hutchinson (1978). All measurements were taken with the stage micrometer and Occular under microscope. Slides were photographed with Olympus research trinocular microscope.

\section{Result and Discussion:-}

Two species of Bivalves viz. Lemellidens marginalis (Lamarck) and Parreysia favidens (Benson) were recorded from river Gomti and Other water reservoirs in and around Lucknow (U.P.) India.

\section{Lemellidens marginalis:-}

(Plate1, Figs 1and2) The shell of L. marginalis was thin, sub elliptical with slightly inflated beaks. The Hinge in the right shell valve is not two llamellar pseudocardinal teath, situated one below the above. The left shell valve there is only a single pseudocardinal tooth which resembles a feebly developed ridge. The lateral teeth are somewhat curved, and there being two in left and one in right shell valve. Both the pairs of gills are marsupials. L. marginalis are found embedded or ploughing its way in the soft sand or mud near the bank or lying, submerged in the water, at limes hardly visible. While moving hinge is dorsal, shell valves lateral, gap between valves ventral, at posterior end there exhalent and inhalant siphons.

The shell of Lemellidens marginalis consists of two almost equal lateral valves united by dorsal ligament. Each valve is an elongate elliptical structure rounded in its anterior margin but obtusely pointed with a slight post dorsal low biangulate posterior ridge. The shell valves ranges from $68-88 \mathrm{~mm}$ in length and $38-45 \mathrm{~mm}$ in width in middle of the body. Outer surface is convex, brownish black and more or less rough and light brown borders along ventral margins while inner surface is concave shiny pearly white and smooth, sometimes with bluish tinge. Outer surface bears concentric marking (lines of growth) encircling a slightly elevated cone, Umbo near the anterior. Posterior side is broad, roundedly angular, wings very narrow and with two cardinals in right valves.

\section{Parreysia favidens:-}

The shell of $P$. favidens is sub-rhomboidal with rounded anterior end and almost posterior pointed end. Shell is somewhat round with narrow wing and umbo measuring 45-60 $\mathrm{mm}$ in length and 30-38 mm in width in middle part of the body. Concentric lines of growth are visible on the outer convex side of the shell. Periostracum is brown to black in colour while inner nacreous layer is shining white which in some specimens appears straw coloured. Shell of Parreysia spp. are heavy, thick and inflates rounded or sub-rhomboidal with distinct radial zig-zag ribs on the beaks. Cardinals heavy, ragged or ventrally striate, lamellar teeth short, cavity of beak somewhat deep. All four gills are marsupials. This species are usually found submerged in the water deep in the silt and are hardly visible. These are sluggish and slow mover in comparison to L. marginalis in laboratory conditions. Exhalent and inhalant siphons are relatively lesser active and responds feebly to light and sound stimuli in comparison to highly sensitive siphons of L. marginalis

\section{Microscopic structure of shell:-}

The Microscopic strucute of shell represents generalized bivalves pattern having distinct three layers (1) outer most periostracum (II) middle prismatic layer and (III) inner nacreous layers. The shell of L. marginalis (Plate 1; Fig 3 \& 4 ) is thin having total thickness in dorsal, middle and ventral regions as, $1.92 \pm 0.24,1.096 \pm 0.06$ and $1.05 \pm 0.08 \mathrm{~mm}$ respectively. periostracum is thinnest outer most layer measuring $0.026 \pm 0.0 \mathrm{~mm}, 0.024 \pm 0.002 \mathrm{~mm}, 0.026 \pm 0.008$ $\mathrm{mm}$ in dorsal, middle and ventral region respectively. Middle layer is made up of blocks of aragonite having $0.11 \pm 0.027,0.10 \pm 0.01,0.062 \pm 0.009 \mathrm{~mm}$ thickness in dorsal, middle and ventral region respectively. The inner most 
nacreous layers is the thickest and layer $0.971 \pm 0.023,0.011 \pm 0.11,0.833 \pm 0.019 \mathrm{~mm}$ thick in dorsal, middle ventral region of the shell. Nacreous layer has laminates structure and in some of the sections secondary and tertiary prismatic and periostracal layers are also seen.

The shell of $P$. favidens was found much thicker than L. marginalis having $2.33 \pm 0.21,1.797 \pm 0.13$ and $0.945 \pm 0.06$ $\mathrm{mm}$ thick in dorsal, middle and ventral part of the shell respectively. Periostracum layer was $0.03 \pm 0.004$, $0.044 \pm 0.006$ and $0.031 \pm 0.004 \mathrm{~mm}$ thick in dorsal, middle and ventral region respectively. Middle prismatic layer was $0.208 \pm 0.03,0.217 \pm 0.03$ and $0.192 \pm 0.018 \mathrm{~mm}$ thick in dorsal, middle and ventral margins respectively. The inner most nacreous layer was almost double than L. marginalis, $20.65 \pm 0.33,1.383 \pm 0.13$ and $0.767 \pm 0.08 \mathrm{~mm}$ in dorsal, middle and ventral margins respectively. The nacreous layer of $P$. favidens was shining white sometimes with straw coloured tinge in comparison to shining white nacre some time with bluish tinge of L. marginalis.

Freshwater mussels are important constituents of freshwater aquatic ecosystem, their diversity and abundance is mainly dependent on physico-chemical characteristic of water as well as soil (Shinde, 2016). Being important creatures of fresh water pearl industry lots of studies have been done on them (Gosling, 2003; Crabarkiewicz and Davis, 2008; Dailians, 2010; Martin et al., 2012; Bhuiyan et al., 2013) but very few attempts have been made in India (Thomas, 1974; Pashupuleti and Subba Rao, 2015). Freshwater mussels are also important source of food and medicine apart from their industrial use (Safaktullah and Krishnamoorti, 2014; Dhaneswari and Sanjeevi, 2016).

Freshwater bivalves have been widely studied by Thomas (1974), Subbarao (1987), Safaktullah (2012) and Shinde (2016). The L. marginalis and P. favidens reported in present study from Lucknow (U.P. India are almost similar to the reporting of Thomas (1974), Subba Rao (1987), Safaktullah and Krishnamoorti (2014) except minor variations in size and colouration of shell. Out of these two mussels L. marginalis is primarily used in fresh water pearl culture while $P$. favidens has potential to produce good quality pearls.

Microstructure of shell of both the species represent typical bivalve shell structure having outer thin peristomium, middle crystalline box like prismatic layer and innermost nacreous layer with growth lines. These observation are in accordance with the findings of Thomas (1974); Ravindranath and Ravindranath (1974); Balkrishnan (1981); Begum et al. (1993) and Begum and Sinha (2000). Both the species have oragonite crystals in prismatic layer along with organic matrix (Ravindranath and Ravindranath, 1974; Martin et al., 2012; Paula de and Silvesia, 2009). Use of fresh water bivalves is increasing day by day in fresh water pearl industry which is mainly limited to L. marginalis but $P$. favidens have different quality, lusture and thicker nacreous layer, is also a promising candidate for freshwater pearl culture. This species is hardy and can survive even in adverse aquatic environment like sandy soil having lesser organic matter (Mishra et al., 2009; Safaktullah et al., 2012).

Various anthropogenic activities enhancing load of xenobiotics in aquatic environment which in turn affects behaviour, physiology and survival of these important creatures. Bivalves accumulates xenobiotics in soft tissues as well as in their shell structure is also affected, therefore can serve as better bio-indicators in environmental monitoring (Crabarkiewicz and Davis, 2008; Sultana et al., 2016).

Both the species of mussels reported in present study from Lucknow (U.P.) India have potential for their use in fresh water pearl industry. After proper standardization of various behavioural, physiological and histological parameters, these can be used in environmental monitoring as reported earlier by Dailians (2010). Due to increased load of pollution, population density of these bivalves is at decline and studies are needed regarding their reproduction and culture techniques which are a mandatory requirement of their industrial use. Studies on them will also be of academic importance as L. marginalis is a type animal of syllabi of various Indian Universities. Such studies will be taken due to course of time.

\section{Conclusion:-}

Two species of freshwater mussels Lamellidens marginalis (Lamarck) and Parreysia favidens (Benson) have been reported from Lucknow (U.P.) India. Shell microstructure of both the species is indicative of their use in freshwater pearl industry. Various behavioural, physiological and histological parameters have potential to use as good biomarkers in relation to environmental monitoring. Both the species have potential to use as bio-indicator of aquatic pollution. 

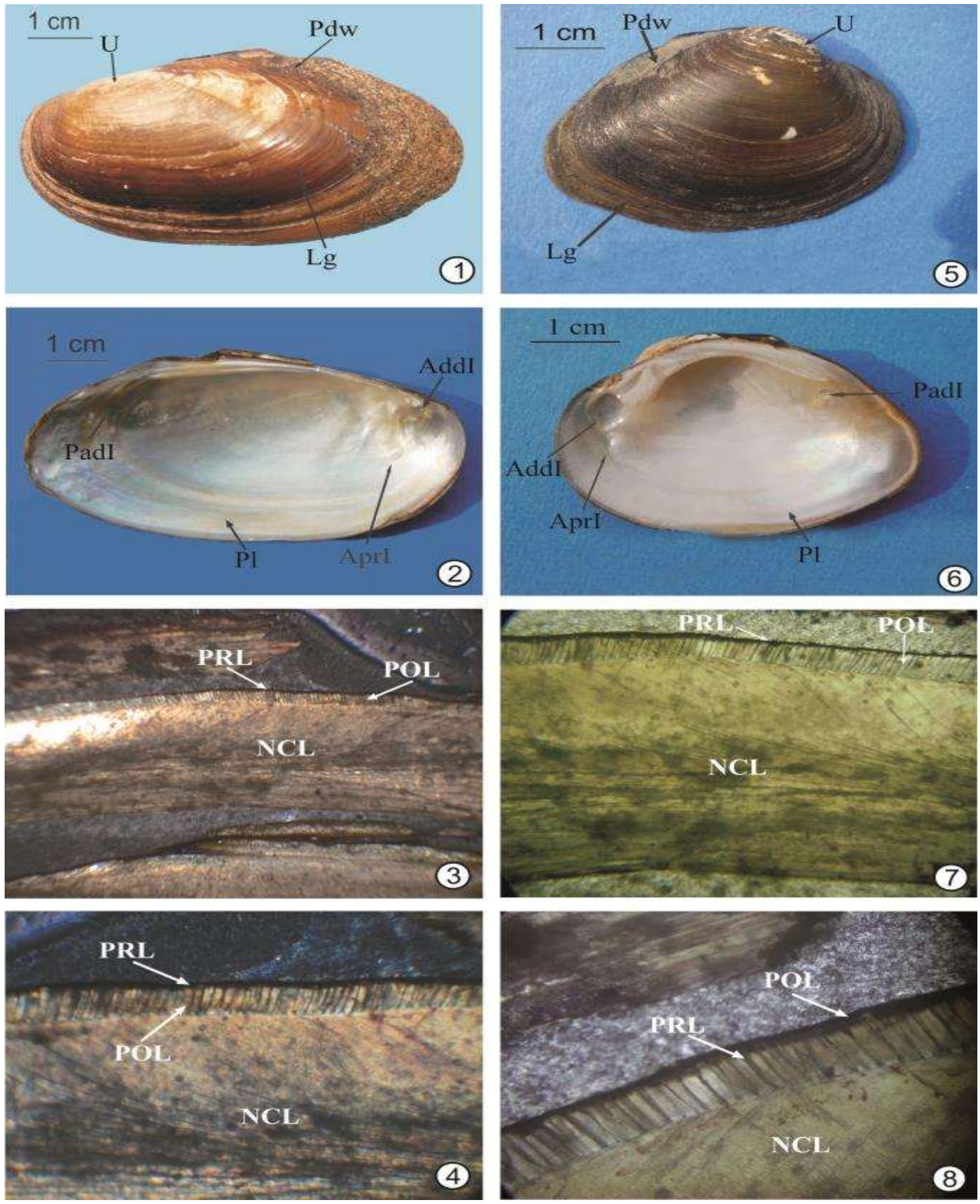

\section{Explanation of figures:}

Figs. 1-4 Lamellidens marginalis; Fig.1-External View of shell; Fig.2 -Internal View of shell; Fig. 3 \& 4- T.S. of shell (X40 \& X100 respectively)

Figs. 5-8 Parreysia favidens; Fig. 5-External View of shell; Fig.6 -Internal View of shell; Fig.7 \& 8- T. S. of shell (X40 \& X100 respectively) (U=Umbo, Pdw=Post dorsal wing, Lg=Lines of growth, $\mathrm{Pl}=$ Pallial lines, PadI=Posterior adductor Impression, AddI=Anterior adductor Impression, AprI=Anterior protractor Impression, $\mathrm{POL}=$ Periostracum Layer, $\mathrm{PRL}=$ Prismatic Layer, $\mathrm{NCL}=$ Nacreous Layer). 


\section{Acknowledgements:-}

Authors are thankful to Director, Zoological Survey of India, Kolkata for identification of bivalve specimens and Principal, B.S.N.V. P.G. College, Lucknow (U.P.) India for encouragement during course of present work.

\section{References:-}

1. Abbot, R.T. (1989): Compendium of land shells. Burlington. MA American Malacologists. 1-240.

2. Bagum, S. and Sinha, A.K. (2000): Length-weight relationship of Parreysia favidens of fresh water Drainage system of Burhi Gandak, North Bihar (India). Rec. Zool. Surv. India. 98(3): 61-66.

3. Balakrishnan, S. (1981): On the Periostrachum of the fresh water Bivalve Lamellidens marginalis. Proc. Indian. Acad. Sci. (Anim. Sc.). 90(1): 79-86.

4. Begum, S., Kumar, C. and Duttamunshi, J.S. (1993): Growth analysis of a fresh water Bivalve, Parreysia favidens of Kori River Basin. J. Fresh water Biology., 5(4): 315-320.

5. Bhuiyan, M.M.S., Rahman, M.R., Jahan, M.S. and Haqne, M. (2013): New records of some fresh water mussels (Bivalvia: Unionidae) from North-east Bangladesh. Bangladesh J. zool., 41(1): 29-42.

6. Dailians, S. (2010): Environmental impact of Anthropogenic activities: The use of mussels as a reliable tool for monitoring Marine Pollution In: Gevin L.E.M. (eds) Mussels: Anatomy, habitat and environmental impact. Nova science Publishers Inc., 1-30.

7. De'Paula, S.M. and Silveria, M. (2009): Studies on Molluscan Shells: contributions from microscopic and analytical methods. Micron., 40: 669-690.

8. Dhanalaxmi, M. and Sanjeevi, S.B. (2016): Antibacterial activity of fresh water Bivalve Lamellidens marginalis (Lamarck 1819) from lower anaicut Reservoir, India. Int. J. Pure. App. Biosci., 4(1): 287-290.

9. Elizabeth Gosling (2003): Bivalve Molluses: Biology, Ecology and cultured Fishing New Books, Black well Science U.K. 7-43.

10. Grabarkieuicz, J.D. and Danis, W.S. (2008): An Introduction to fresh water mussels as Biological Indicators. EPA., 260-R-8-015.

11. HUA.DAN, Mazid, M.A. and Husain, M.G. (2001): Pearl culture, principles and Techniques. Bangladesh Fisheries Research Institute Mimensingh 2201, Bangladesh. 104.

12. Huchinson, C.S. (1978): Laboratory hand book of petrographical techniques Jhonwily.

13. Martin, F., LeRoy, N. and Marie, B. (2012): The formation and minerelization of mollusc shell. Frontiers in Bioscienses., 54: 1099-1125.

14. Misra, G. (2005): Pearl farming - avenue for women entrepreneurship. In Ninawe, A.S. and Diwan, A.D. (eds.) Women Empowerment in Fisheries. Narendra Publishing House, Delhi, India, pp 201 -212

15. Misra, G., Jena, J. and Kumar, K. (2009): Fresh water Pearl crop; an emerging enterprice in the Indian subcontinent. Aquaculture Asia Magazine., 14(4): 26-27.

16. Pasupuleti, R. and Subba Rao, N.V. (2015): A report on extended distribution of a rare Indian fresh water mussel species (Mollusca:- Bivalvia: Unionidae). Advances in applied Science Research., 6(4): 162-165.

17. Ravindranath, M.H. and Ravindranath, M.H.R. (1974): The chemical nature of shell of Mollusca: I. Prismatic and naccrous layer of a Bivalve Lamellidens marginalis (Unionidae). Acta. Histochem. Bd., 48 (5): 26-41.

18. Safakatullah, N. and Krishnamoorthy, M. (2014): Nutritional quality in fresh water mussel, Parreysia spp. of Periyar river. Kerala. India. Research J. of Recent sci., (3): 267-270.

19. Shafakatullah, N., Lobo, R.O., Krishnamoorthy, M. and Thippeswamy, S. (2012): A study on the diversity of fresh water bivalves in the rivers of Karnataka and Kerala, South India. J. Sci. Trans. Environ. Technov., 5(4): 212-214.

20. Shinde, N.G. (2016): Biodiversity and threats to native plecypode (Bivalves) molluses along the selected sites of Godavari river of Western Maharashtra. Flora and fauna., 22(2):281-290.

21. Subba Rao, N.V. (1989): Hand book of fresh water molluses of India, Zoological Survey of India, Calcutta. 164-192.

22. Sultana, S., Siddiki, A.K.M.N., Rokonujjaman, Md., Naser, M.N., Salam, A., Salam, A.Md. A. (2016): Heavy metal accumulation in fresh water Mussel (Lamellidens marginalis) as a biological monitor inhabiting in Dhan mondi Lake Dhaka, Bangladesh. International J. Bioassay., 59: 4933-4938.

23. Thomas, E.I. (1974): The bionomics, Anotomy and development of the fresh water mussel, Lamellidens marginalis (Lamarck). Annals of zoology, 10(4): 77-170.

24. Verma, D.R., Lodhi, H.S., Tiwari, K.J., Shukla, S. and Sharma, U.D. (2010): Copper sulphate induced changes in scaphognathite oscillations and oxygen consumption of fresh water prawn, Macrobrachium lamarrei (Crustacea Decapoda). J. of Appl. and Nat. Sci., 2(1): 34-37. 